\title{
Original
}

\section{Dual Nature of TGF- $\beta 1$ in Osteoblastic Differentiation of Human Periodontal Ligament Cells}

\author{
Hiromi Ochiai ${ }^{1,5)}$, Yasuhito Yamamoto'), Akiko Yokoyama ${ }^{1)}$, Haruto Yamashita ${ }^{3)}$, \\ Kenichi Matsuzaka ${ }^{4)}$, Shinichi Abe ${ }^{2,5)}$ and Toshifumi Azuma ${ }^{1,4,5)}$ \\ 1) Department of Biochemistry, Tokyo Dental College, 1-2-2, Masago, Mihama-ku, Chiba City, 261-8502, Japan. \\ 2) Department of Anatomy, Tokyo Dental College, 1-2-2, Masago, Mihama-ku, Chiba City, 261-8502, Japan. \\ 3) Department of Pediatric Dentistry, Tokyo Dental College, 1-2-2, Masago, Mihama-ku, Chiba City, 261-8502, Japan. \\ 4) Oral Health Science Center hrc7, Tokyo Dental College, 1-2-2, Masago, Mihama-ku, Chiba City, 261-8502, Japan. \\ 5) Oral Health Science Center hrc8, Tokyo Dental College, 1-2-2, Masago, Mihama-ku, Chiba City, 261-8502, Japan.
}

(Accepted for publication, November 9, 2010)

\begin{abstract}
This study investigated the effect of various treatments with TGF- $\beta 1$ in osteogenic differentiation of human periodontal ligament (HPDL) cells.

HPDL cells were treated with single $1 \mathrm{ng} / \mathrm{ml}, 100 \mathrm{ng} / \mathrm{ml}$ or multiple (12-h intervals) $1 \mathrm{ng} / \mathrm{ml} \mathrm{TGF-} \beta 1$. Alkaline phosphatase (ALP) activity was detected by ALP activity staining at 4 days. Phospho-Smad3 was detected by western blotting and transcription of osteogenic differentiation markers (RUNX2, ALPL, IBSP: bone sialoprotein, $B G L A P$ : osteocalcin) were determined by real-time PCR at various culture periods. Cells were pretreated with or without SB505124, a TGF- $\beta /$ Smad pathway inhibitor, for $1 \mathrm{~h}$ before $1 \mathrm{ng} / \mathrm{ml} \mathrm{TGF-} \beta 1$ treatment at $12-\mathrm{h}$ intervals. ALP activity and phosphorylated Smad3 were detected.

Single treatment with $1 \mathrm{ng} / \mathrm{ml}$ TGF- $\beta 1$ significantly induced Smad3 phosphorylation, subsequent ALP upregulation and transcription of osteogenic differentiation markers, compared to these inductions with 100 $\mathrm{ng} / \mathrm{ml}$ TGF- $\beta 1$ treatment. In multiple treatments with $1 \mathrm{ng} / \mathrm{ml} \mathrm{TGF-} \beta 1$ at 12 -h intervals, only the first treatment significantly induced Smad3 phosphorylation but not the succeeding treatments. Inductive effects of single 1 ng/ml TGF- $\beta 1$ in osteogenic differentiation were almost completely abolished by multiple treatments. Furthermore, multiple treatments with $1 \mathrm{ng} / \mathrm{ml}$ TGF- $\beta 1$ did not induce ALP activity although the TGF- $\beta / \mathrm{Smad}$ pathway was inhibited by SB505124.

Single treatment with low dose TGF- $\beta 1$ significantly induced osteogenic differentiation. Multiple treatments inhibited osteogenic differentiation despite inhibition of TGF- $\beta /$ Smad pathway. These findings suggest that TGF- $\beta 1$ both positively and negatively regulates osteogenic differentiation and the inhibitory effect may be mediated by the non-Smad signaling pathway in HPDL cells.
\end{abstract}

Key words: TGF- $\beta 1$, Periodontal ligament, Osteogenesis, Smad3 protein, Phosphorylation

\section{Introduction}

The periodontal ligament (PDL) is a connective tissue consisting of heterogeneous population which includes undifferentiated mesenchymal cells, osteoprogenitors, and fibroblasts. Cells in PDL exhibit the potential to differentiate into osteoblasts in vitro. ${ }^{1)}$ A recent study reported that human PDL contains stem cells and consequently PDL stem cells have the potential to generate cementum/PDL-like tissue. ${ }^{2,3)}$ Therefore, PDL is featured as a useful source of regenerative therapy.

Transforming growth factor- $\beta 1$ (TGF- $\beta 1$ ) plays a pivotal role in connective tissue regeneration and bone remodeling. Previous

Corresponding to: Dr. Toshifumi Azuma, Postal address: Department of Biochemistry, Tokyo Dental Collage 1-2-2, Masago, Mihama-ku, Chiba City, 261-8502, Japan. Tel: +81-43-270-3750, Fax: +81-43-270-3752, E-mail: tazuma@tdc.ac.jp reports demonstrated that TGF- $\beta 1$ has significant effects in osteogenic differentiation and bone formation. ${ }^{4-8)}$ TGF- $\beta 1$ increased mRNA levels of osteoblastic differentiation markers and alkaline phosphatase (ALP) activity in murine bone marrow stromal cells. $\left.{ }^{6}\right)$ TGF- $\beta 1$ was rapidly and transiently increased in orthodontic tooth movement and was associated with bone remodeling in vivo. ${ }^{9)}$ On the other hand, TGF- $\beta 1$ blocked osteogenesis by a variety of mechanisms depending on cell density, TGF- $\beta 1$ concentration and differentiation stage of the cells. ${ }^{10-12)}$ TGF- $\beta 1$ also blocked odontogenesis by downregulation of dentin sialophosphoprotein. ${ }^{13)}$ The mitogen-activated protein kinase (MAPK) pathway has been proposed to negatively regulate Smad pathway and osteoblast mineralization. ${ }^{14,15)}$ Some studies reported that TGF- $\beta 1$ has biphasic and concentration-dependent effects on 
J.Hard Tissue Biology Vol. 19(3):187-194, 2010

Table 1. Primer and probe sets for quantitative real-time PCR analysis

\begin{tabular}{|c|c|c|c|c|}
\hline Gene symbol & GeneBank accession no. & Primer sequence: sense/antisense & Probe no. & Amplicon \\
\hline RUNX2 & NM_001024630.2 & $\begin{array}{l}\text { 5'-gtgcctaggcgcatttca-3' } \\
\text { 5'-gctcttcttactgagagtggaagg-3' }\end{array}$ & $\# 29$ & $78 \mathrm{bp}$ \\
\hline ALPL & NM_000478.3 & $\begin{array}{l}\text { 5'-caaccctggggaggagac-3' } \\
5^{\prime} \text {-gcattggtgttgtacgtcttg-3' }\end{array}$ & $\# 19$ & $78 \mathrm{bp}$ \\
\hline IBSP & NM_004967.3 & $\begin{array}{l}\text { 5'-caatctgtgccactcactgc-3' } \\
\text { 5'-tcattttggtgattgettcct-3' }\end{array}$ & \#38 & $74 \mathrm{bp}$ \\
\hline BGLAP(osteocalcin) & NM_199173.3 & $\begin{array}{l}\text { 5'-tgagagccetcacactcetc-3' } \\
5^{\prime} \text {-acctttgctggactctgcac-3' }\end{array}$ & $\# 81$ & $98 b p$ \\
\hline SMAD7 & NM_005904.2 & $\begin{array}{l}\text { 5'-cgatggattttctcaaaccaa-3' } \\
5^{\prime} \text {-attcgttccccetgtttca-3' }\end{array}$ & $\# 69$ & $74 \mathrm{bp}$ \\
\hline SMAD3 & NM_005902.3 & $\begin{array}{l}5^{\prime} \text {-ccacgcagaacgtcaaca-3' } \\
5^{\prime} \text {-gatgggacacctgcaacc -3' }\end{array}$ & $\# 9$ & $72 b p$ \\
\hline GAPDH & NM_002046.3 & $\begin{array}{l}\text { 5'-agccacatcgetcagacac-3' } \\
5^{\prime} \text {-gcccaatacgaccaaatcc-3' }\end{array}$ & $\# 60$ & $66 b p$ \\
\hline
\end{tabular}

osteogenic differentiation. ${ }^{10,16,17)}$ These ambiguous results may be due to variation in the cell models used to analyze TGF- $\beta 1$ function.

TGF- $\beta$ family-induced Smad pathway involve two different classes of serine/threonine kinase receptors called types I and II. ${ }^{18)}$ TGF- $\beta$ interact with heterotetrameric complexes of type I and II receptors, which lead to phosphorylation-dependent activation of the dormant type I receptor kinase, in turn, phosphorylated downstream substrates, called receptor-regulated Smads (RSmads). ${ }^{19)}$ Smad1, Smad5 and Smad8 are activated by BMPs and Smad 2 and Smad 3 are activated by TGF- $\beta$ or activins. These RSmads, which formed hetero-oligomeric complexes with common Smad (Smad4), translocate to the nucleus where they function as transcription factors via direct DNA binding. ${ }^{20)}$ Inhibitory Smads (I-Smad), including Smad6 and Smad7, act as inhibitors of TGF$\beta$ family signaling pathway. ${ }^{21,22)}$ In addition, non-Smad pathways directly or indirectly modify Smad phosphorylation and regulate TGF- $\beta$ function. ${ }^{23)}$

Although these reports suggested that TGF- $\beta /$ Smad pathway could be the major player for induction of osteogenesis, they did not fully explain either the dual effect of TGF- $\beta$ signaling or the mechanism by which TGF- $\beta 1$ influences osteogenesis. To better understand the signaling pathways mediating TGF- $\beta 1$ in PDL cells, we examined the activation of Smad pathway and the role of TGF$\beta 1$ in osteoblastic differentiation of human PDL (HPDL) cells.

\section{Materials and Methods}

\section{Cell culture and osteogenic differentiation}

Normal HPDL cells, defined as pan cytokeratin negative, were purchased from Lonza (Basel, Switzerland) and cultured in BulletKit $^{\circledR}$ Stromal cell growth medium (SCGM, Lonza). Passage was done for 5 to 8 times and cells were seeded at $1 \times 10^{5} \mathrm{cells} / \mathrm{cm}^{2}$ in SCGM for each assay. Osteogenic differentiation was induced by replacing the osteogenic differentiation medium (OBM), composed of $\alpha$-MEM (Invitrogen, Carlsbad, CA, USA) supplemented with 5\% FBS (Invitrogen), $50 \mathrm{mg} / \mathrm{ml} \mathrm{L-ascorbic}$ acid (Wako Pure Chemical Industries Ltd., Osaka, Japan) and 10 mM $\beta$-glycerophosphate (Wako), with or without rhTGF- $\beta 1$ (Wako) which was added the following day. The cells were also treated with or without $10 \mathrm{nM}$ dexamethasone (Dex, SigmaAldrich, St. Louis, MO, USA) and 0.5 $\mu$ M SB-505124 (SigmaAldrich), a competitive inhibitor of activin receptor-like kinase (ALK) 5 that mediates TGF- $\beta$-receptor signaling. For single treatment with TGF- $\beta 1$, the medium was not changed until day 4 . In the process of multiple treatments with TGF- $\beta 1$, OBM containing fresh TGF- $\beta 1$ was changed every $12 \mathrm{~h}$.

\section{Assay of alkaline phosphatase (ALP) activity}

For ALP staining, the cells were fixed in 4\% paraformaldehyde for $5 \mathrm{~min}$ at room temperature. The cells were then washed with PBS and incubated with ALP substrate solution (Roche Diagnostics, Basel, Switzerland) for $1 \mathrm{~h}$ at room temperature. After washing with distilled water for three times, images were captured with phase-contrast microscope. To measure ALP activity, cells 
A

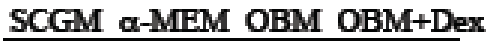

B
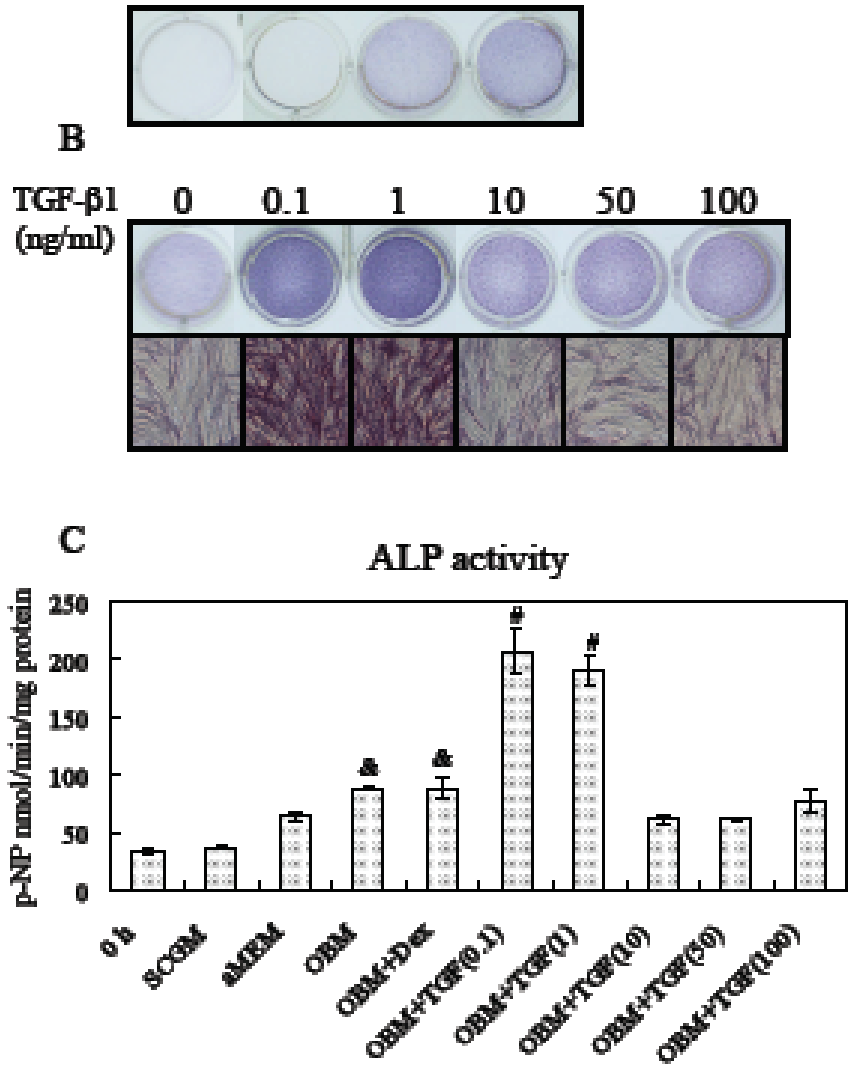
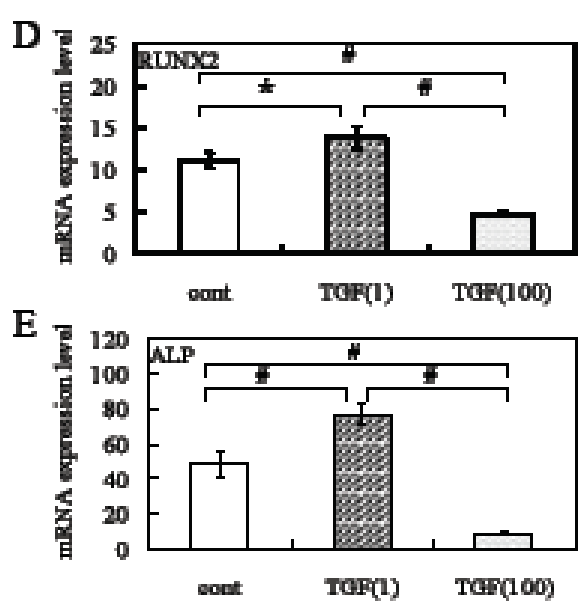

$\mathbf{F}$

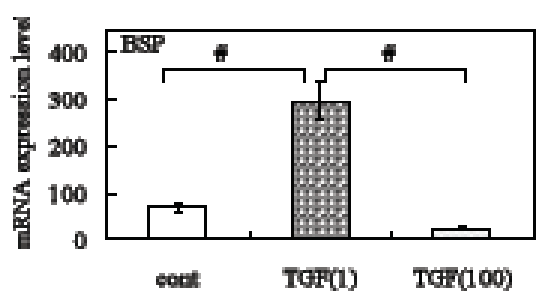

Figure 1. Influence of TGF- $\beta 1$ in osteogenic differentiation of HPDL cells. (A) Confluent HPDL cells were cultured in various culture media (SCGM, $\alpha$-MEM, OBM, OBM + $10 \mathrm{nM}$ Dexamethasone [Dex]) for 4 days and stained for ALP activity. (B) Confluent HPDL cells were cultured in OBM with or without TGF- $\beta 1(0.1,1,10,50$ or $100 \mathrm{ng} / \mathrm{ml})$ for 4 days and were then stained with ALP. Upper panel is the macroscopic appearance of the wells. Lower panel is the phase-contrast microscope images $(\times 100)$ of the cells in wells. $(C)$ The cells were cultured in various culture media or various concentration of TGF$\beta 1$ for 4 days after which ALP activity was measured. $\# \mathrm{P}<0.001$ compared with SCGM, $\alpha-\mathrm{MEM}, \mathrm{OBM}, \mathrm{OBM}+\mathrm{Dex}, \mathrm{TGF}(10)$, TGF(50) or TGF(100). \&P $<0.001$ compared with SCGM, $\alpha$-MEM, TGF(0.1), TGF(1), TGF(10) or TGF(50). (D-F) The mRNA expression levels of osteogenic differentiation genes Runx2 (D), ALP (E), and BSP (F) in HPDL cells treated with 1 $\mathrm{ng} / \mathrm{ml}$ TGF- $\beta 1$ (TGF[1]) or $100 \mathrm{ng} / \mathrm{ml} \mathrm{TGF-} \beta 1$ (TGF [100]) for 4 days, or untreated with TGF- $\beta 1$ (cont), were examined by qRT-PCR. The expression levels of each gene were normalized with GAPDH and a value of 1 was assigned to HPDL cells at day 0 . Three wells were performed (A, B). Each experiment was performed in triplicate, and the data represent the means \pm $\mathrm{SD}$. The Bonferroni correction for multiple comparisons was applied. ${ }^{*} \mathrm{P}<0.01,{ }^{\sharp} \mathrm{P}<0.001$.

were washed twice with PBS and lysed with lysis buffer $(10 \mathrm{mM}$ Tris-Hcl [pH 7.5], $150 \mathrm{mM} \mathrm{NaCl}$, complete protease inhibitor mixture and $1 \% \mathrm{NP}-40)$. ALP activity was assayed using $p$ nitrophenylphosphate as a substrate and the protein content was measured with DC Protein Assay Kit (BioRad Laboratories, Hercules, CA, USA) according to the manufacturer's instructions. ALP activity was expressed as nmol $p$-nitrophenol(pNP)/ min/ mg of protein.

\section{Quantitative real-time PCR ( $q R T-P C R)$}

Total RNA was extracted from cultured cells using QIAzol reagent (Qiagen Inc., Valencia, CA, USA) according to the manufacturer's instructions. cDNA was synthesized using high- capacity cDNA reverse transcription kit (Applied Biosystems, Foster City, CA, USA). qRT-PCR analysis was performed using Premix Ex Taq ${ }^{\mathrm{TM}}$ reagent (Takara Bio Inc., Shiga, Japan) according to the manufacturer's instructions. The target genes were RUNX2, alkaline phosphatase $(A L P L)$, bone sialoprotein $(I B S P)$ and osteocalcin (BGLAP). GAPDH was used as an internal control. All primers and probes of these target genes presented in Table 1 were designed using Probefinder v2.45 (http://qper. probefinder.com/roche3.html).

\section{Protein extraction and immunoblotting}

The cells were lysed with lysis buffer (10 mM Tris-Hcl [pH 7.5], $150 \mathrm{mM} \mathrm{NaCl}$, complete protease inhibitor mixture, $1 \mathrm{mM}$ 
A

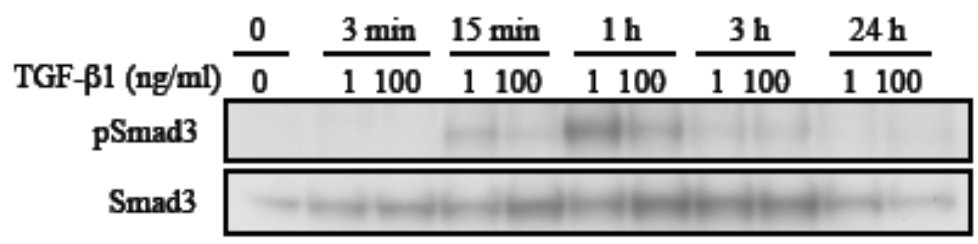

B

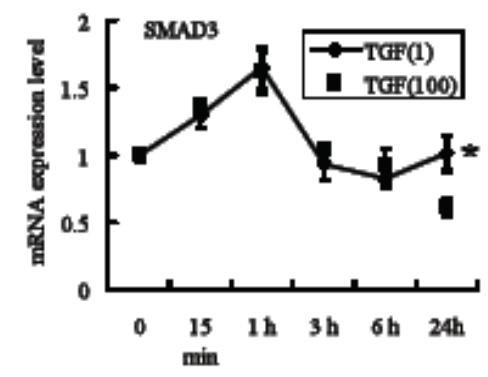

C

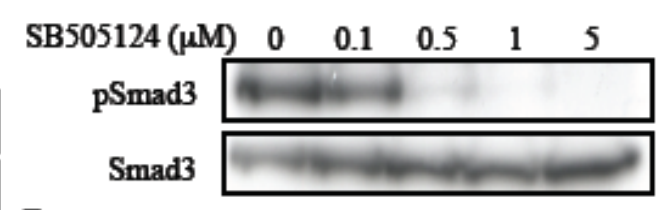

D

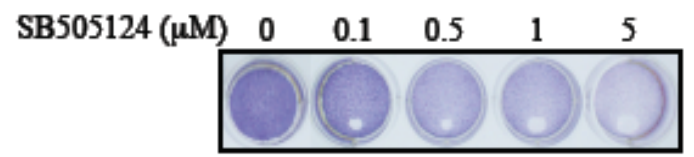

Figigure 2. Effect of TGF- $\beta 1$ on Smad3 phosphorylation and mRNA expression and of inhibition of ALK kinase on TGF$\beta 1$-induced Smad3 phosphorylation and osteogenic differentiation in HPDL cells. (A) Cells were incubated for $12 \mathrm{~h}$ in serum-free medium and were treated with 1 or $100 \mathrm{ng} / \mathrm{ml} \mathrm{TGF-} \beta 1$ for the indicated times. Western blot analysis using specific antibodies against phospho-Smad3 and Smad3 was then performed. (B) Cells were incubated in OBM with 1 or $100 \mathrm{ng} / \mathrm{ml}$ TGF- $\beta 1$ for the indicated times. Smad 3 mRNA expression was analyzed by qRT-PCR. SMAD3 mRNA expression levels were normalized with GAPDH. A value of 1 was assigned to HPDL cells at 0 min. The cells were pretreated with SB505124 $(0.1,0.5,1,5 \mu \mathrm{M})$, an ALK5 inhibitor, for $1 \mathrm{~h}$ in serum free media before treatment with TGF- $\beta 1$ (1 ng/ml) together with SB505124. (C) Cells extracts were prepared 30 min after treatment and pSmad3 and Smad3 were analyzed by Western blotting. (D) The cells were stained for ALP activity at $96 \mathrm{~h}$ after treatment. The number of wells performed three (D). All experiments were repeated three times and representative results were shown. The data represent the means $\pm \mathrm{SD} . * \mathrm{P}<0.01$ compared with $\mathrm{TGF}(100)$ using Student's t-test.

sodium orthovanadate and $1 \% \mathrm{NP}-40)$, and the protein content was measured with DC Protein Assay Kit. Equivalent protein concentrations were resolved on NuPAGE 7\% Tris-Acetate gels (Invitrogen) by electrophoresis and transferred to a PVDF membrane. The membrane was probed with anti-phosphorylated Smad3 or anti-Smad3 antibodies (1: 1000 for phosphorylated Smad3 and Smad3; Cell Signaling Technology Inc., Danvers, MA, USA), followed by HRP-conjugated goat anti-rabbit IgG. Bound antibodies were visualized using chemiluminescent substrate (ECL plus, GE Healthcare UK Ltd., Buckinghamshire) and exposed to Hyperfilm ECL (GE Healthcare).

\section{Statistical analysis}

Each experiment was repeated three times. When ANOVA indicated differences among the groups, multiple comparisons of each experimental group were performed using Bonferroni test.

\section{Results}

Characterization of HPDL cells and the effect of TGF- $\beta 1$ in osteogenesis

OBM or OBM + Dex treatment significantly increased ALP activity in HPDL cells (Fig. 1A and 1C). TGF- $\beta 1$ was added to HPDL cells at different concentrations $(0,0.1,1,10,50$, and 100 $\mathrm{ng} / \mathrm{ml}$ ). Both the number of ALP positive cells and intensity of staining strongly increased in low dose TGF- $\beta 1$ treatment (Fig. 1B). ALP activity was strongly induced by 0.1 or $1 \mathrm{ng} / \mathrm{ml} \mathrm{TGF-}$ $\beta 1$, but weakly induced by $10 \mathrm{ng} / \mathrm{ml}$ or higher TGF- $\beta 1$ compared to low dose TGF- $\beta 1$ (Fig. 1C). Runx2 mRNA expression was significantly increased by $1 \mathrm{ng} / \mathrm{ml} \mathrm{TGF}-\beta 1$, but was strongly down regulated (to a level much lower than the control group) by 100 ng/ml TGF- $\beta 1$ treatment (Fig. 1D). Similar results were observed when mRNA expression of ALP or BSP was assayed (Fig. 1E and $1 F)$. Thus, the effect of TGF- $\beta 1$ in the expression of these osteogenic markers was inversely proportional to the concentration of TGF- $\beta 1$.

\section{Strong phosphorylation of Smad3 by a low dose of TGF- $\beta 1$ promoted osteogenic differentiation of HPDL cells}

Strong phosphorylation of Smad3 was detected following treatment of cells with $1 \mathrm{ng} / \mathrm{ml}$ TGF- $\beta 1$ for $1 \mathrm{~h}$. This phosphorylation was stronger than that observed for $100 \mathrm{ng} / \mathrm{ml}$ TGF- $\beta 1$ (Fig. 2A). Smad3 mRNA expression was altered by TGF$\beta 1$ treatment over time (Fig. 2B). The observed variation in Smad3 protein may be due to changes in the expression level of Smad3 mRNA expression. HPDL cells were treated with $1 \mathrm{ng} / \mathrm{ml}$ TGF$\beta 1$ in the presence of ALK5 inhibitor SB505124 for $30 \mathrm{~min}$ (Fig. 
A
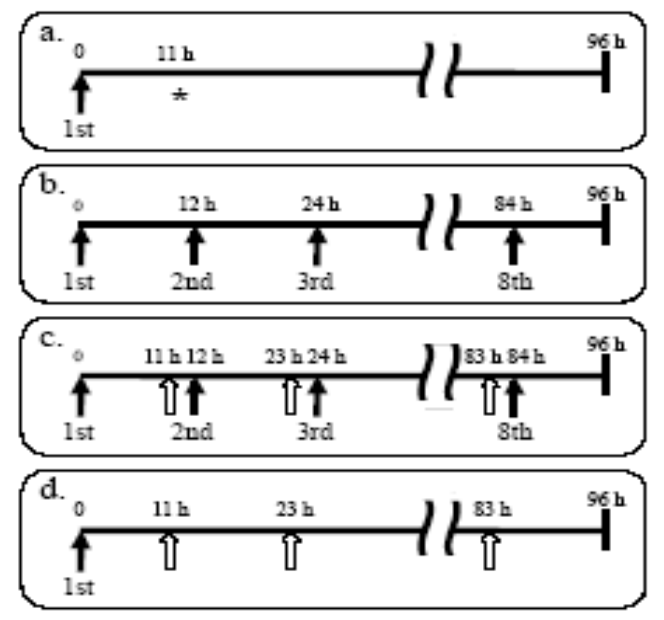

B

$\mathrm{pSmad} 3$

Smad3

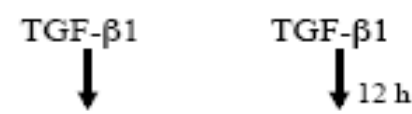

$0 \frac{15 \mathrm{~m}}{1 \mathrm{~h}} \underline{12 \mathrm{~h}} \underline{15 \mathrm{~m}} \underline{13 \mathrm{~h}}$

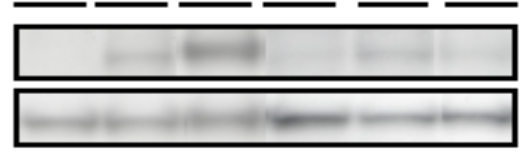

$\mathrm{C}$
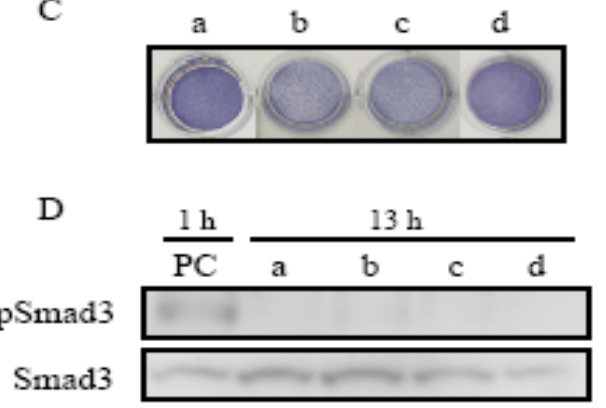

Figure 3. Effect of multiple treatments of low dose TGF- $\beta 1$ on Smad3 phosphorylation in, and osteogenic differentiation of, HPDL cells. (A) TGF- $\beta 1$ treatment protocol. The filled arrow indicates the time at which $1 \mathrm{ng} / \mathrm{ml}$ TGF- $\beta 1$ was added. The open arrow indicates the time at which $0.5 \mu \mathrm{M}$ SB505124 was added. (a) The cells were exposed to a single $1 \mathrm{ng} / \mathrm{ml} \mathrm{TGF}-\beta 1$. Medium without TGF- $\beta 1$ was changed at $11 \mathrm{~h}(*)$. (b) The cells were exposed to $1 \mathrm{ng} / \mathrm{ml}$ TGF- $\beta 1$ at $12 \mathrm{~h}$ intervals. (c) The cells were exposed to $1 \mathrm{ng} / \mathrm{ml} \mathrm{TGF}-\beta 1$ at $12 \mathrm{~h}$ intervals after pretreatment with $0.5 \mu \mathrm{M}$ SB505124 for $1 \mathrm{~h}$. (d) The cells were exposed to $1 \mathrm{ng} /$ $\mathrm{ml}$ TGF- $\beta 1$ alone first and were subsequently exposed $0.5 \mu \mathrm{M}$ SB505124. (B) Cells were incubated for $12 \mathrm{~h}$ in serum-free medium and were treated with $1 \mathrm{ng} / \mathrm{ml}$ TGF- $\beta 1$ for the indicated times. Western blot analysis using specific antibodies against phospho-Smad3 and Smad3 was then performed. (C) The cells were stained for ALP at $96 \mathrm{~h}$ after (a), (b), (c) or (d) treatment. (D) Western blot analysis of pSmad3 and Smad3 in cell lysates on (a), (b), (c) or (d) treatment at $13 \mathrm{~h}$ after the first TGF- $\beta 1$ addition. Positive control (PC) was the cell lysate at $1 \mathrm{~h}$ after the first $1 \mathrm{ng} / \mathrm{ml}$ TGF- $\beta 1$ treatment. The number of wells performed three (C). All experiments were repeated three times, and representative results was shown.

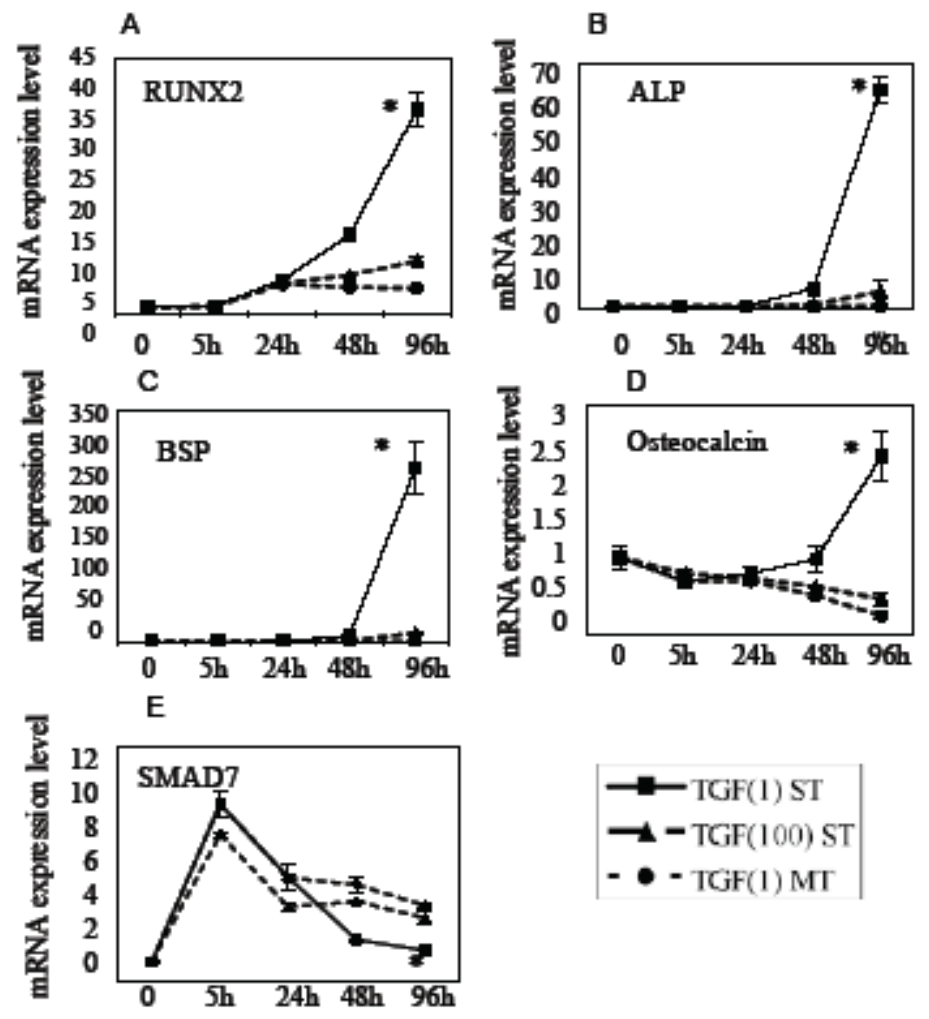

Figure 4. Time course analysis of the effect of TGF$\beta 1$ concentration and schedule of administration in the expression of osteogenic differentiation markers. The cells were treated with a single treatment (ST) or multiple treatments (MT, every $12 \mathrm{~h}$ ) of $1 \mathrm{ng} / \mathrm{ml}$ TGF- $\beta 1$ (TGF (1)ST or TGF (1)MT) or a ST of 100 $\mathrm{ng} / \mathrm{ml}$ TGF- $\beta 1$ (TGF (100)ST). Total RNA was extracted from the treated cells at indicated time and the mRNA expression of RUNX2 (A), ALP (B), BSP (C), Osteocalcin (D) and SMAD7(E) was examined using qRT-PCR. The expression levels of each gene were normalized with GAPDH with a value of 1 was assigned to HPDL cells at $0 \mathrm{~h}$. Each experiment was performed in triplicate, and the data represent the means $\pm \mathrm{SD}$. The Bonferroni correction for multiple comparisons was applied. ${ }^{*} \mathrm{P}<0.001$ compared with TGF(100) ST or TGF(1) MT. 
2C) or $96 \mathrm{~h}$ (Fig. 2D) after pretreatment with SB505124 for $1 \mathrm{~h}$. SB505124 dose-dependently decreased TGF- $\beta 1$-induced ALP in parallel with a decrease in pSmad3.

\section{Multiple treatments with low dose TGF- $\beta 1$ inhibited osteogenic differentiation}

We then tested the effect of repeated treatment with $1 \mathrm{ng} / \mathrm{ml}$ TGF- $\beta 1$ on HPDL-osteogenic differentiation. As expected, strong phosphorylation of Smad3 was detected after the first treatment with $1 \mathrm{ng} / \mathrm{ml}$ TGF- $\beta 1$ for $1 \mathrm{~h}$ (Fig. 3B). Neither the second nor the third treatments induced much phosphorylation of Smad3 (Fig. $3 \mathrm{~B}$ and data not shown, respectively). The first treatment with 1 ng/ml TGF- $\beta 1$ strongly induced ALP but multiple treatments inhibited ALP expression (Fig. 3C). Inhibition of TGF- $\beta$ / Smad pathway with SB505124 at every $12 \mathrm{~h}$ before TGF- $\beta 1$ treatment failed to induce ALP expression (Fig. 3C). Phosphorylated Smad3 was not detected in SB505124 treatment (Fig. 3D).

\section{Single treatment of low dose TGF- $\beta 1$ induced RUNX2, ALPL, IBSP and BGLAP expression}

As shown in Fig. 4, RUNX2 and $A L P L$ expression began to increase after $24 \mathrm{~h}$ or $48 \mathrm{~h}$ with single $1 \mathrm{ng} / \mathrm{ml}$ TGF- $\beta 1$ treatment. The expression of these mRNAs showed little increase following a single $100 \mathrm{ng} / \mathrm{ml}$ TGF- $\beta 1$ treatment or multiple treatments with $1 \mathrm{ng} / \mathrm{ml}$ TGF- $\beta 1$. A single $1 \mathrm{ng} / \mathrm{ml}$ TGF- $\beta 1$ treatment induced all osteogenic differentiation markers studied here while multiple or $100 \mathrm{ng} / \mathrm{ml}$ TGF- $\beta 1$ treatment reduced them.

SMAD7 is transcriptionally induced by TGF- $\beta$ and negatively regulated TGF- $\beta$ / Smad signaling pathway. ${ }^{21)}$ SMAD7 expression was transiently and strongly induced under all conditions of TGF$\beta 1$ treatment at $2 \mathrm{~h}$, and decreased thereafter (Fig. 4E). Following single $1 \mathrm{ng} / \mathrm{ml}$ TGF- $\beta 1$ treatment, SMAD7 expression continuously decreased and had almost reached the baseline level after $48 \mathrm{~h}$ of treatment. However, following $100 \mathrm{ng} / \mathrm{ml}$ or multiple TGF- $\beta 1$ treatments, SMAD7 expression was maintained at higher levels relative to those following a single $1 \mathrm{ng} / \mathrm{ml}$ TGF- $\beta 1$ treatment at $24 \mathrm{~h}$ and $48 \mathrm{~h}$. The sustained high expression level of SMAD7 may be at least one of the reasons for the observed downregulation of pSmad3 by TGF- $\beta 1$ treatments because SMAD7 inhibits TGF$\beta$-receptor-induced Smad3 phosphorylation.

\section{Discussion}

In this paper we have shown that TGF- $\beta 1$ both positively and negatively regulated osteogenic differentiation of HPDL cells and Smad3 phosphorylation depending on the concentration of TGF$\beta 1$ and its time of administration. HPDL cells used in our study were defined as pan cytokeratin negative cells. Thus they could be heterogenous containing population of mesenchymal cells, osteoprogenitors, and fibroblasts. ${ }^{24)}$ Indeed, we found that HPDL cells expressed $R U N X 2$ at slightly higher levels than normal human dermal fibroblasts (data not shown), and we could barely detect ALP activity in these cells (Fig. 1A). Osteoblast differentiation markers were significantly induced when cultured in OBM. Thus, HPDL cells are capable of differentiating into osteoblasts.

A single low dose of TGF- $\beta 1$ treatment promoted osteogenic differentiation whereas treatment with repetitive low doses, or a single high dose, of TGF- $\beta 1$ had much weaker effects in osteogenic differentiation. Zimmermann et al. reported that serum levels of TGF- $\beta 1$ were significantly higher in bone fracture patients than in normal controls and that lower serum levels of TGF- $\beta 1$ were related to delayed healing of fracture. ${ }^{25)}$ Several other reports also described the key role of TGF- $\beta 1$ in matrix production, osteoblast precursor cell recruitment during bone repair and acceleration of bone formation. ${ }^{425-28)}$ However, in vitro studies showed that TGF$\beta 1$ could positively and negatively regulate osteoblast differentiation depending on the duration of TGF- $\beta 1$ treatment or the differentiation stage of the cells. ${ }^{7,11,15,29)}$ Thus, the exact mechanism by which TGF- $\beta 1$ modulates osteoblast differentiation is unclear.

It was inferred from the results that TGF- $\beta 1$ might initiate osteogenic differentiation with a single low dose TGF- $\beta 1$ treatment of HPDL cells, but repetitive or a single excessive high dose of TGF- $\beta 1$ treatment might actively switch off and suppress osteogenesis. This hypothesis is supported by the effect of different TGF- $\beta 1$ treatments on Smad3 phosphorylation. Thus, treatment with $1 \mathrm{ng} / \mathrm{ml}$ TGF- $\beta 1$ induced strong Smad3 phosphorylation, whereas $100 \mathrm{ng} / \mathrm{ml}$ TGF- $\beta 1$ significantly reduced Smad3 phosphorylation (Fig. 2A). Several previous studies indicated that Smad pathway is a key process by which TGF- $\beta 1$ modulates osteogenesis. Overexpression of Smad3 in MC3T3-E1 cells enhanced ALP activity and mineralization. ${ }^{30)}$ Borton et al. showed that mice with a targeted deletion of Smad3 were osteopenic, had decreased bone mineral density and a decreased rate of bone formation. ${ }^{31)}$ Together with our data (Fig. 2C and 2D), these results suggest that TGF- $\beta /$ Smad pathway (canonical pathway) plays an important role in osteogenic differentiation of HPDL cells. Smad phosphorylation decreased after second treatment with $1 \mathrm{ng} / \mathrm{ml}$ TGF- $\beta 1$ (Fig. 3B). Multiple treatments of TGF- $\beta 1$ abolished the upregulation of ALP and osteogenic differentiation marker genes (Fig. 3C and 4). As shown in Fig. 3A, first, we treated the cells with $1 \mathrm{ng} / \mathrm{ml}$ TGF- $\beta 1$ alone and then at $12 \mathrm{~h}$ later, these cells were treated with TGF- $\beta 1$ with/without ALK5 inhibitor SB505124. We found that osteogenic differentiation was completely abolished regardless of SB505124 treatments (Fig. 3C [b] and [c]). Smad3 phosphorylation was completely inhibited by SB505124 treatment (Fig. 3D). These results indicate that although Smad pathway was not active, the inhibition of osteogenic differentiation occurred by multiple treatments. Thus, we suggest that the inhibition of osteogenic differentiation is associated with non-Smad pathway. We hypothesized that there may be a pathway which inhibits 
Hiromi Ochiai et al.: Effect of TGF- $\beta 1$ in Osteogenic Differentiation of HPDL Cells

Smad3 phosphorylation that is only activated by a high dose or repetitive TGF- $\beta 1$ treatment. This notion is supported by a previous report that $\mathrm{Smad} 3$ overexpression greatly enhanced ALP activity that was inhibited by TGF- $\beta 1$ treatment. ${ }^{30)}$ Several other studies have reported that TGF- $\beta 1$ inhibited osteoblastic differentiation via a non-canonical pathway such as ERK1/2 or JNK pathway. ${ }^{14,15,32)}$ Complex effects of TGF- $\beta 1$ on cell function have been widely reported and have been termed "dual effect" of TGF- $\beta 1.23,29,33,34)$ Non-canonical pathways may play an important role in this dual effect of TGF- $\beta$ signaling. We hypothesize that TGF- $\beta 1$ may have a dual effect in osteogenesis which is either controlling positively or negatively via canonical and noncanonical pathways respectively. Since these non-canonical pathways and their regulation are very complex, further detailed studies are required to fully understand the regulation of osteogenesis by TGF- $\beta$ signaling.

In conclusion, a low dose of TGF- $\beta 1$ induced Smad3 phosphorylation and enhanced the expression of osteogenic differentiation markers. However, repetitive or high dose TGF$\beta 1$ treatment inhibited Smad3 phosphorylation and enhanced the expression of osteogenic differentiation markers. Smad3 phosphorylation plays an important role in osteogenesis whereas the non-canonical pathway may have an inhibitory function. These studies confirmed that TGF- $\beta 1$ has a dual effect in osteogenesis and further studies of this dual effect will contribute to a better understanding of the pathological mechanism of periodontitis that will lead to new therapies.

\section{Acknowledgements}

This study was supported by Grant hrc7, 8 from the Oral Health Science Center of Tokyo Dental College and a "High-Tech Research Center" Project for Private Universities.

\section{References}

1. Zhou Y, Hutmacher DW, Sae-Lim V, Zhou Z, Woodruff M and Lim TM. Osteogenic and adipogenic induction potential of human periodontal cells. J Periodontol 79: 525-534, 2008

2. Seo BM, Miura M, Gronthos S, Bartold PM, Batouli S, Brahim J, Young M, Robey PG, Wang CY and Shi S. Investigation of multipotent postnatal stem cells from human periodontal ligament. Lancet 364: 149-155, 2004

3. Tomokiyo A, Maeda H, Fujii S, Wada N, Shima K and Akamine A. Development of a multipotent clonal human periodontal ligament cell line. Differentiation 76: 337-347, 2008

4. Janssens K, Dijke PT, Janssens S and Hul WV. Transforming growth factor-b1 to the bone. Endocr Rev 26: 743-774, 2005

5. Lee JY, Kim KH, Shin SY, Rhyu IC, Lee YM, Park YJ, Chung $\mathrm{CP}$ and Lee SJ. Enhanced bone formation by transforming growth factor-b1-releasing collagen/chitosan microgranules.
J Biomed Mater Res A 76: 530-539, 2006

6. Zhao L, Jiang and Hantash BM. Transforming growth factor b1 induces osteogenic differentiation of murine bone marrow stromal cells. Tissue Eng Part A 16: 725-733, 2010

7. Lee KS, Hong SH and Bae SC. Both the Smad and p38 MAPK pathways play a crucial role in Runx2 expression following induction by transforming growth factor-b and bone morphogenetic protein. Oncogene 21: 7156-7163, 2002

8. Ripamonti U, Ferretti C, Teare J and Blann L. Transforming growth factor-b isoforms and the induction of bone formation. J Craniofac Surg 20: 1544-1555, 2009

9. Uematsu S, Mogi M and Deguchi T. Increase of transforming growth factor-b1 in gingival crevicular fluid during human orthodontic tooth movement. Arch Oral Biol 41: 1091-1095, 1996

10. Zhang H, Ahmad M and Gronowicz G. Effects of transforming growth factor-beta 1 (TGF- $\beta 1)$ on in vitro mineralization of human osteoblasts on implant materials. Biomaterials 24:2013-2020, 2003

11. Alliston T, Choy L, Ducy P, Karsenty G and Derynck R. TGF- $\beta$-induced repression of CBFA1 by Smad3 decreases cbfa1 and osteocalcin expression and inhibits osteoblast differentiation. EMBO J 20: 2254-2272, 2001

12. Kaji H, Naito J, Sowa H, Sugimoto T and Chihara K. Smad3 differently affects osteoblast differentiation depending upon its differentiation stage. Horm Metab Res 38: 740-745, 2006

13. He WX, Niu ZY, Zhao SL, Jin WL, Gao J and Smith AJ. TGF- $\beta$ activated Smad signalling leads to a Smad3-mediated down-regulation of DSPP in an odontoblast cell line. Arch Oral Biol 49: 911-918, 2004

14. Kwok S, Partridge NC, Srinivasan N, Nair SV and Selvamurugan N. Mitogen activated protein kinasedependent inhibition of osteocalcin gene expression by transforming growth factor-b1. J Cell Biochem 106: 161169, 2009

15. Sowa H, Kaji H, Yamaguchi T, Sugimoto T and Chihara K. Activations of ERK1/2 and JNK by transforming growth factor $b$ negatively regulate Smad3-induced alkaline phosphatase activity and mineralization in mouse osteoblastic cells. J Biol Chem 277: 36024-36031, 2002

16. Aspenberg P, Jeppsson C, Wang JS and Boström M. Transforming growth factor beta and bone morphogenetic protein 2 for bone ingrowth: A comparison using bone chambers in rats. Bone 19: 499-503, 1996

17. Centrella M, Ji C, Casinghino S and McCarthy TL. Rapid flux in transforming growth factor-b receptors on bone cells. J Biol Chem 271: 18616-18622, 1996

18. Massagué J and Chen YG. Controlling TGF- $\beta$ signaling. Genes Dev 14: 627-644, 2000

19. Shi Y and Massagué J. Mechanisms of TGF- $\beta$ signaling from 
cell membrane to the nucleus. Cell 113: 685-700, 2003

20. Massague $J$ and Wotton D. Transcriptional control by the TGF- $\beta$ /Smad signaling system. EMBO J 19: 1745-1754, 2000

21. Yan X, Liu Z and Chen Y. Regulation of TGF- $\beta$ signaling by Smad7. Acta Biochim et Biophys Sin (Shanghai) 41: 263272, 2009

22. Miyazono K. Positive and negative regulation of TGF- $\beta$ signaling. J Cell Sci 113: 1101-1109, 2000

23. Derynck R and Zhang YE. Smad-dependent and Smadindependent pathways in TGF- $\beta$ family signalling. Nature 425: 577-584, 2003

24. Nagata S, Nozaki T, Ohura K and Daito M. Analysis of gene expression during differentiation induction of normal human periodontal ligament cells into osteoblast lineage. J Oral Tissue Engin 6: 88-96, 2008

25. Zimmermann G, Henle P, Küsswetter M, Moghaddam A, Wentzensen A, Richter W and Weiss S. TGF- $\beta 1$ as a marker of delayed fracture healing. Bone 36: 779-785, 2005

26. Carrington JL, Roberts AB, Flanders KC, Roche NS and Reddi AH. Accumulation, localization, and compartmentation of transforming growth factor $\mathrm{b}$ during endochondral bone development. J Cell Biol 107: 1969-1975, 1988

27. Devescovi V, Leonardi E, Ciapetti G and Cenni E. Growth factors in bone repair. Chir Organi Mov 92: 161-168, 2008

28. Sumner DR, Turner TM, Purchio AF, Gombotz WR, Urban RM and Galante JO. Enhancement of bone ingrowth by transforming growth factor-b. J Bone Joint Surg Am 77: 1135-1147, 1995

29. Chaudhury A and Howe PH. The tale of transforming growth factor-beta (TGF $\beta$ ) signaling: A soigné enigma. IUBMB Life 61: 929-939, 2009

30. Sowa H, Kaji H, Yamaguchi T, Sugimoto T and Chihara K. Smad3 promotes alkaline phosphatase activity and mineralization of osteoblastic MC3T3-E1 cells. J Bone Miner Res 17: 1190-1199, 2002

31. Borton AJ, Frederick JP, Datto MB, Wang X and Weinstein RS. The loss of $\mathrm{Smad} 3$ results in a lower rate of bone formation and osteopenia through dysregulation of osteoblast differentiation and apoptosis. J Bone Miner Res 16: 17541764, 2001

32. Miyazono A, Yamada A, Morimura N, Takami M, Suzuki D, Kobayashi M, Tezuka K, Yamamoto M and Kamijo R. TGF$\beta$ suppresses POEM expression through ERK1/2 and JNK in osteoblasts. FEBS Lett 581: 5321-5326, 2007

33. Moustakas A and Heldin CH. Non-Smad TGF- $\beta$ signals. J Cell Sci 118: 3573-3584, 2005

34. Rahimi RA and Leof EB. TGF- $\beta$ signaling: A tale of two responses. J Cell Biochem 102: 593-608, 2007 